\title{
UPAYA MENINGKATKAN KEMAMPUAN RESEPTIF DAN EKSPRESIF BAHASA ANAK KELOMPOK B TK DENGAN BERBAGAI METODE YANG MENARIK
}

\author{
Novi Luthfiyah \\ Universitas Muhamadiyah Jakarta \\ luthfiyah.novi@gmail.com
}

\begin{abstract}
Early childhood experiences a very rapid development of abilities. Appropriate stimulation is needed for the development process. Language ability is an important stimulation because it is the basis for developing other abilities. Classroom action research by conducting two cycles using various learning methods and activities was carried out at TKIT Nurul Iman with the aim of improving Receptive and Expressive Language skills in group B children. .8\%, 27.2\% less, 36\% enough, $34.6 \%$ good, and $0 \%$ very good. In the second cycle there was an increase compared to before the learning improvement was made. In this cycle, the data obtained were $0 \%$ very less, $0 \%$ less, $11 \%$ enough, $51 \%$ good, and $38 \%$ very good. So the improvement of children's Receptive and Expressive Language learning has met the required complete standard of $80 \%$, where children master the indicators well as much as $89 \%$. So it can be concluded that there was a significant increase from Cycle I to Cycle II.
\end{abstract}

Keywords: Stimulation, Expressive and Receptive Language, Learning method.

\section{ABSTRAK}

Anak usia dini mengalami perkembangan kemampuan yang sangat pesat. Dibutuhkan stimulasi yang tepat untuk proses pengembangan tersebut. Kemampuan Bahasa merupakan stimulasi penting karena merupakan dasar untuk mengembangkan kemampuannya yang lain. Penelitian tindakan kelas dangan melakukan dua siklus menggunakan metode dan kegiatan pembelajaran yang bervariasi ini dilaksanakan di TKIT Nurul Iman dilakukan dengan tujuan untuk meningkatkan kemampuan Bahasa Reseptif dan Ekspresif pada anak kelompok B. Hasil peneitian menunjukan pada Sklus I peneliti mendapatkan data kemampuan anak yang kurang sekali 1,8\%, kurang 27,2\%, cukup 36\%, baik 34,6\%, dan 0\% baik sekali. Pada siklus II mengalami peningkatan dibandingkan sebelum dilakukan perbaikan pembelajaran. Pada siklus ini diperoleh data sebanyak 0\% kurang sekali, 0\% kurang, 11\% cukup, 51\% baik, dan 38\% baik sekali. Maka perbaikan pembelajaran Bahasa Reseptif dan Ekspresif anak telah memenuhi standar tuntas yang diperlukan yaitu $80 \%$, di mana anak menguasai indikator dengan baik sebanyak 89\%. Maka dapat disimpulkan terjadi peningkatan secara signifikan dari Siklus I ke Siklus II.

Kata kunci: Stimulasi, Bahasa Ekspresif dan reseptif, Metode pembelajaran.

\section{PENDAHULUAN}

Pada abad 18 ada beberapa pendapat yang berbeda tentang definisi bahasa. Monks, Knoers, dan Haditono (1984) sebagaimana dikutip oleh Nurbiana Dhieni dkk menyatakan bahwa menurut aliran Sofisme bahasa sebagai suatu perjanjian yang sifatnya disengaja antara masyarakat. Selanjutnya Aliran Stoijin memandang bahasa sebagai suatu kemampuan yang bersifat alamiah. Plato dan Aristoteles mengartikan bahasa sebagai interaksi antara dua pandangan tersebut

Untuk mengembangkan kemampuan Bahasa diperlukan metode yang tepat. Bagi Anak Usia Dini yang berusia antara 5-6 tahun (Kelompok B) seharusnya memiliki kemampuan bahasa dalam menyimak, berbicara, terutama perbendaharaan kata yang mulai banyak sehingga merupakan masa peka untuk 
mencerna informasi yang disampaikan. pada usia ini anak mengalami perkembangan yang pesat dalam semua kemampuan yang akan menentukan untuk masa depannya. Jika diibaratkan membangun sebuah rumah, maka masa ini adalah masa membangun pondasi rumah yang akan menentukan kekokohan rumah tersebut. Selain itu, perlu juga dikemukakan bahwa dengan stimulasi yang tepat akan menghasilkan pribadi yang berkualitas yang dapat menghadapi kehidupannya kelak.

Berdasarkan pengalaman mengajar, anak-anak pada kelompok B mengalami kendala dalam menyampaikan informasi tentang suatu hal yang tidak dekat dengan kehidupaannya. Untuk mengatasi ini diperlukan metode yang tepat, pemilihan kata-kata yang sesuai dengan tingkat pemahaman mereka, dan pemilihan media dan alat peraga yang tepat agar dapat dimengerti oleh anak. Dengan pengalaman mengajar ini dapat dipahami bahwa ternyata kemampuan reseptif dan ekspresif (dimengerti/diterima) anak usia 5-6 tahun berkembang sangat pesat dan memerlukan stimulasi yang tepat. Untuk itu dipandang perlu melakukan penelitian tindakan kelas untuk meningkatkan kemampuan bahasa anak usia 5-6 tahun. Penelitian ini akan mencoba mencari metode, media dan alat peraga serta pemilihan bahasa yang tepat sehingga kemampuan bahasa Anak dapat berkembang dengan baik, begitu juga dengan pengembangan kemampuankemampuan yang lainnya.

Dari hasil evaluasi kegiatan pembelajaran yang dilaksanakan ternyata ditemukan beberapa masalah yang teridentifikasi di antaranya (a) penguasaan materi yang disampaikan kurang dari $60 \%$, (b) ketika kegiatan berdiskusi anak belum terlibat aktif didalamnya, (c) pada saat bermain peran maupun sosio drama sebagian anak belum dapat mengungkap-kan ekspresinya, (d) begitu juga tidak dapat mengungkapkan pengalaman atau sesuatu hal yang di rasakan, (e) strategi pembelajaran yang kurang menarik sehingga anak menjadi bosan, dan (f) metode dan media pembelajaran yang digunakan kurang menarik.

Setelah mengidentifikasi masalah yang terjadi pada saat kegiatan belajar mengajar dengan cara refleksi maka ditemukan masalah dalam hal kemampuan reseptif dan ekspresif anak, kemampuan dalam menyajikan pembelajaran dan kemampuan penggunaan bahasa yang kurang tepat untuk anak usia 5-6 tahun.

Masalah penelitian ini dirumuskan sebagai berikut: "bagaimana cara meningkatkan kemampuan reseptif dan ekspresi anak Kelompok B diTKIT Nurul Iman Padurenan, Gunungsindur Bogor"

Tujuan penelitian tindakan kelas yang dilakukan ini adalah untuk meningkatkan kemampuan dalam mengajar dan untuk dapat mengatasi masalah di TK kelompok B yang dihadapi. yang akan meningkatkan kemampuan bahasa anak didik terutama dalam hal kemampuan reseptif dan ekspresinya sehingga dapat menguasai materi yang disampaikan dan dapat mengungkapkan yang ada dipikiran anak didik menjadikannya pribadi yang matang mampu menyerap semua informasi yang didapatkannya dan mampu mengungkap-kan kemampuannya tersebut ketika dewasa kelak.

\section{KAJIAN LITERATUR}

\section{Anak usia dini}

\section{a) Hakikat anak usia dini}

Anak adalah anugrah terindah yang Allah berikan kepada orang tua, anak yang baru dilahirkan sampai berusia enam tahun adalah pada fase usia dini, pada masa ini anak mengalami pertumbuhan dan perkembangan yang sangat pesat dari berbagai bidang meliputi perkembangan fisik motorik, seni, bahasa, kognitif, moral dan sosial emosi dewasa, jadi perkembangan kecerdasan berkembang sangat pesat pada manusia di saat hidupnya berada pada masa usia dini, maka sangat disayangkan sekali apabila pada saat anak mengalami masa peka mendapatkan pendidikan ataupun simulasi yang kurang tepat. Potensi kecerdasannya 
menjadi mati dan dapat menghambat perkembangannya ketika dewasa karena pendidikan anak usia dini adalah modal dasar untuk kemajuan masa depannya diibaratkan seorang anak itu adalah rumah apabila dibuat pondasi yang kokoh maka untuk dibangun mau dengan bentuk apapun akan kokoh pula. Begitu pula sebaliknya apabila pondasi rumah itu dibangun asal-asalan maka akan cepat roboh. Jadi apabila seorang anak yang mendapatkan pendidikan di masa usia dininya sesuai maka akan terbentuk pribadi yang kokoh, cerdas dan mempunyai kemampuan untuk menghadapi masalah apapun yang dihadapinya. Oleh karenanya diperlukan stimulasi-stimulasi yang tepat agar semua potensi yang dimilikinya dapat berkembang dengan pesat.

\section{c. Karakteristik anak usia dini}

Untuk memberikan simulasi yang tepat maka seorang guru wajib memahami beberapa karakteristik anak didik agar pembelajaran yang diberikannya tepat sesuai dengan indikator yang diharapkan. Mengutip Siti Aisyah dkk (2010: 1.7) karakteristik anak usia dini antara lain memiliki rasa ingin tahu yang besar, merupakan pribadi yang unik, suka berfantasi dan berimajinasi, masa paling potensial untuk belajar, menunjukan masa egosentris, memiliki rentang daya konsentrasi yang pendek, dan sebagai bagian dari makhluk sosial.

Terdapat beberapa titik masa kritis yang perlu diperhatikan pada anak usia dini, yaitu: membutuhkan rasa aman, istirahat dan makanan yang baik. Datang kedunia yang diprogram untuk meniru. Membutuhkan rutinitas dan latihan. Memiliki kebutuhan untuk banyak bertanya dan memperoleh jawaban. Cara berfikir anak berbeda dengan orang dewasa. Membutuhkan pengalaman langsung. Trial and eror (uji coba) menjadi pokok dalam pembelajaran. Bermain merupakan dunia masa anakanak.

\section{Konsep Bahasa}

Kesepakatan Bersama manusia untuk menggunakan simbol-simbol yang diucapkan dengan lisan maupun secara tertulis disebut dengan Bahasa. Beberapa definisi tentang bahasa dapat dikemukakan sebagai berikut (Nurbiana Dhieni dkk, 2009):

Menurut Badudu Bahasa adalah alat penghubung atau komunikasi antara anggota masyarakat yang terdiri dari individu-individu yang menyatakan pikiran, perasaan dan keinginan. Jadi dalam hal ini bahasa merupakan suatu sistem lambang yang digunakan sebagai alat komunikasi oleh anggota masyarakat yang bersifat arbiter dan manusiawi.

Menurut Bromley Bahasa merupakan simbol yang teratur untuk mentransfer berbagai ide maupun informasi yang terdiri dari simbol-simbol visual maupun verbal. Simbol-simbol visual itu dapat dibaca, dilihat dan ditulis, sedangkan simbol-simbol verbal dapat diucapkan dan didengar.

Menurut Llyod Bahasa adalah sistem simbol yang teratur untuk mentransfer arti yang dikomunikasikan, jadi suatu modifikasi komunikasi yang meliputi sistem simbol khusus yang dipahami dan digunakan sekelompok individu untuk mengkomunikasikan berbagai ide dan informasi. Komunikasi dimaksud tidak berbatas pada bahasa verbal. Ketika beberapa orang bersama berada di suatu tempat pasti terjadi komunikasi sekalipun mereka tidak berbicara, bisa melalui bahasa tubuh, ekspresi wajah, dan suara-suara non-linguistic seperti menggumam ataupun menggerutu.

Kemampuan bahasa seseorang didapat-kan sejak dia berada dalam kandungan. Ketika seorang ibu yang sedang mengandung dia berbicara sambil mengelus-elus perutnya maka janinpun akan merespon dengan menggerakan tubuhnya sehingga terjalinlah komunikasi yang sederhana, begitupun ketika didengarkan lagu-lagu klasik maka akan dapat merangsang perkembangan kemampu-an otaknya dengan pesat, begitu pula ketika dia lahir senyuman dan tangisan pun sebagai bahasa bayi pertama untuk mengungkapkan yang dia inginkan ini bukti bahwa bahasa adalah kemampuan 
awal yang dianugerahkan sang Pencipta kepada manusia sebelum kemampuankemampuannya yang lain.

\section{a. Bahasa Menurut Sifatnya}

Menurut Bromley, seperti dikutip oleh Nurbiana Dhieni dkk (2009) terdapat empat macam Bahasa yaitu: menyimak, membaca, berbicara, dan menulis. Kemampuan bahasa berbeda dengan kemampuan berbicara, bahasa merupakan suatu sistem tata bahasa yang relatif rumit dan bersifat sematik, sedangkan kemampuan berbicara merupakan suatu ungkapan dalam bentuk kata-kata. Menurut sifatnya, ada dua macam bahasa yaitu: (a) Reseptif (dimengerti / diterima) contoh: mendengarkan dan membaca suatu informasi, dan (b) ekspresif (dinyatakan) contohnya: berbicara dan menuliskan informasi untuk dikomunikasikan kepada orang lain.

Dalam hal ini kemampuan reseptif dan ekspresif pada masing-masing individu akan berbeda, akan berpengaruh pada kemampuannya ketika dia bersosialisasi, ketika menyerap informasi yang didapat dan untuk mengungkapkan atau menyampaikan sesuatu yang dipikirkannya. Untuk mnjadikan seorang individu yang mempunyai kemampuan bahasa yang baik maka diperlukan peranan dari berbagai pihak terutama orangtua dan keluarga karena pertama kali anak mengenal dan belajar bahasa dari lingkungan yang paling dekat dan yang paling sering berinteraksi dengan anak tersebut. Apabila dalam keluarga tersebut menggunakan tata bahasa yang baik maka kemampuan bahasa anaknya pun akan baik. Begitu juga sebaliknya.

\section{b. Tujuan perkembangan bahasa}

Campebel dan Dickison seperti dikutip Sujiono dan Sujiono (2004) menjelaskan bahwa tujuan pengembangkan kecerdasan linguistik anak adalah agar anak (a) mampu berkomunikasi dengan baik lisan maupun tulisan dengan baik, (b) memiliki kemampuan bahasa untuk menyakinkan orang lain, (c) mampu mengingat, manghafal informasi dan memberikan informasi, dan (d) mampu membahas bahasa itu sendiri.

\section{Metode Pembelajaran}

Terdapat berbagai metode pembelajaran yang sesuai dengan karakteristik anak yang dapat diterapkan agar pembelajaran dapat dilakukan dengan menyenangkan, antara lain metode bercakap-cakap, tanya jawab, bercerita, demonstrasi, bernyanyi, karyawisata, metode pemberian tugas, metode eksperimen, dan metode bermain peran (Nurbiana Dhieni dkk, 2009).

\section{METODE PENELITIAN}

Penelitian dilaksanakan di TKIT NURUL IMAN di perumahan Taman Sari Bukit Damai Desa Padurenan Kecamatan Gunungsindur Bogor, pada tahun ajaran 2019-2020.

Penelitian ini dilakukan dengan menggunakan metode Penelitian Tindakan Kelas (PTK). Suradika dan Dirgantara (2019: 108) menyatakan bahwa PTK merupakan suatu pencermatan terhadap kegiatan kelas berupa tindakan yang disengaja dimunculkan dan terjadi dalam sebuah kelas secara Bersama.

Di TKIT tersebut terdapat 34 murid yang terdiri dari kelompok bermain empat anak, kelompok A delapan anak, kelompok B1 11 anak, kelompok B2 11 anak. Siswa yang diteliti adalah kelompok B1 berjumlah 11 anak terdiri dari 5 anak perempuan dan 6 anak lakilaki.

Perbaikan pembelajaran dilaksanakan selama 10 hari dengan menggunakan siklus 1 dan siklus 2 sebagaimana layaknya dalam PTK. Tiap siklusnya dilaksanaknan dalam lima hari.

Data dianalisis melalui dua tahap, yaitu tahap (a) rencana pengamatan. Peneliti akan meneliti kegiatan yang telah direncanakan dan mengumpulkan data selama kegiatan berlangsung dengan bermacam macam metode pembelajaran. Data dikumpulkan dengan dengan teknik observasi, tanya jawab, bercerita, bermain peran, berdiskusi, dan performen, dan (b) refleksi yang 
dilakukan setelah kegiatan pembelajaran selesai dan siswa sudah pulang. Kegunaan refleksi adalah untuk mengetahui kelemahan maupun kelebihan pembelajaran yang telah dilakukan untuk meningkatkan kualitas pembelajaran dan untuk merencanakan kegiatan pada siklus selanjutnya.

\section{HASIL DAN PEMBAHASAN}

\section{Deskripsi Hasil Penelitian}

\section{a. Perbaikan Pembelajaran}

\section{Siklus pertama}

\section{- Hari pertama.}

Kegiatan perbaikan pem-belajaran yang dilakukan peneliti pada hari pertama adalah kegiatan tanya jawab tentang negara Indonesia dan bernyanyi lagu Bendera Merah Putih yang bertujuan untuk meningkatkan kemampuan ekspresi dan reseptifnya. Diperoleh data anak yang masih kurang sekali $0 \%$, kurang $28 \%$, cukup $36 \%$ dan $36 \%$ baik. Hal ini dikarenakan penggunaan media pembelajaran yang baru dan menarik minat anak, namun penggunaan bahasa yang disampaikan kurang di mengerti anak sehingga tidak semua anak paham dengan materi yang disampaikan dan terlibat dalam tanya jawab untuk dapat mengungkapkan pendapatnya.

\section{- $\quad$ Hari kedua}

Kegiatan perbaikan pem-belajaran pada hari kedua berjalan cukup baik dengan kegiatan yang dilakukan adalah bercerita satu persatu tentang pengalaman yang dialaminya, bercerita dengan menggunakan media wayang dan menceritakan kembali isi cerita diperoleh data sebanyak $0 \%$ kurang sekali, 9\% kurang $36 \%$ cukup dan $55 \%$ baik. Hal ini terjadi karena mengguna-kan media pembelajaran yang dapat menarik minat anak akan tetapi dikarenakan keterbatasan jumlah wayang sehingga tokoh cerita kurang bervariasi.

- $\quad$ Hari ketiga.

Kegiatan perbaikan pem-belajaran pada hari ketiga bermain kuda bisik dan menceritakan isi gambar yang dilengkapinya. Didapatkan data $0 \%$ kurang sekali, $45 \%$ kurang, 36\% cukup dan $19 \%$ baik. Terjadi penurunan di karenakan kegiatan bercerita isi gambar cerita anak-anak kurang bervariasi karena anak hanya melengkapi gambar yang disediakan oleh peneliti. Kelebihannya adalah kegiatan pengembangan yang di-lakukan adalah menggunakan metode bermain kuda bisik anak lebih cepat dan senang menguasai kosakata baru ketika menemukan kata baru yang mereka belum paham artinya, timbul diskusi diluar rencana pembelajaran sehingga menambah wawasan anak.

\section{- $\quad$ Hari keempat}

Pada hari keempat kegiatan perbaikan pembelajaran mengucapkan sajak sederhana, bercakap-cakap tentang isi sajak dan mengenal nama-nama pulau yang ada di Indonesia dari hasil penilaian terjadi penurunan pada penguasaan kemampuannya yaitu $9 \%$ kurang sekali, $55 \%$ kurang dan $36 \%$ cukup, $0 \%$ baik disebabkan anak belum terbiasa mengucapkan sajak dan pengalokasian waktu yang kurang maka tidak semua anak maju kedepan secara individu, sehingga belum diketahui penguasaannya dan untuk penilaian kurang maksimal, akan tetapi penggunaan syair sajak yang sesuai dengan tahap perkembangan anak dan dengan menggunakan media atlas anak-anak mengenal pulau secara sederhana membuat anak senang tidak cepat bosan.

- Hari kelima

Kegiatan perbaikan pembelajaran pada hari kelima berdiskusi tentang tema yang dibahas dalam satu minggu dan bermain peran tema "Pahlawan Indonesia" anak-anak terlihat antusias sehingga kemampuan pembelajaran mengalami peningkatan, di mana $0 \%$ kurang sekali, $0 \%$ kurang, 36\% cukup dan 64\% Baik, Kelebihan kegiatan pengembangan yang dilakukan adalah kegiatan yang dapat menarik minat anak dan penggunaan properti yang menarik sehingga indikator yang diharapkan dapat tercapai, akan tetapi pengalokasian 
waktu yang kurang karena jam belajar hari jum'at lebih singkat sehingga anak belum puas.

\section{Siklus kedua}

\section{- Hari pertama}

Kegiatan perbaikan pem-belajaran Siklus II pada hari pertama mengucapkan sajak sederhana pada kegiatan ini peneliti menyadari bahwa setiap anak itu unik sesuai dengan teori karakteristik anak di mana kemampuan anak kadang tidak terduga yang pendiam bisa jadi lebih berani begitu pula kebalikannya. Dari hasil penilaian didapatkan data kemampuan anak mengalami peningkatan, yaitu $0 \%$ kurang sekali, $0 \%$ kurang, 9\% cukup, 55\% baik dan 36\% baik sekali. Hal ini karena peneliti memberikan kesempatan untuk semua anak maju satu persatu mengucapkan sajak sehingga dapat dinilai secara akurat, akan tetapi peneliti ketika mengajarkan isi sajak terlalu cepat ada beberapa anak yang belum hafal benar.

\section{- $\quad$ Hari kedua}

Kegiatan perbaikan pem- belajaran pada hari kedua adalah kegiatan menyebutkan macam-macam suara binatang dan menceritakan isi gambar yang dibuatnya. Hasilnya $0 \%$ kurang sekali, $0 \%$ kurang, $0 \%$ cukup, $18 \%$ baik dan $82 \%$ baik sekali. Hal ini disebabkan kegiatan pembelajaran yang peneliti lakukan meng-gunakan metode yang bervariasi sehingga anak tidak bosan dengan kegiatan pembelajaran yang dilaksanakan. Kelemahan pada kegiatan ini jumlah binatang yang ada diposter tidak banyak sehingga tidak semua anak mendapatkan giliran untuk menyebutkan suara binatang tersebut.

\section{- $\quad$ Hari Ketiga}

Kegiatan perbaikan pem-belajaran pada hari ketiga "Bemain kartu perintah menirukan gerakan macam-macam binatang dan bernyanyi lagu kodok". Didapatkan data $0 \%$ kurang sekali, $0 \%$ kurang, $18 \%$ cukup, $73 \%$ baik, dan $9 \%$ baik sekali. Dengan mengenalkan lagu baru anak bersemangat menyanyikannya karena lagunya lucu dan dengan melakukan permainan menirukan gerakan binatang anak senang, Kelemahan ketika melakukan kegiatan bermain kartu perintah menirukan gerakan binatang karena kegiatan didalam ruangan sehingga gerak anak kurang leluasa.

\section{- $\quad$ Hari keempat}

Pada hari keempat kegiatan perbaikan pembelajaran yang dilakukan bermain peran tema binatang. Diperoleh data kemampuan anak yang kurang sekali $0 \%$, kurang $0 \%$, cukup $9 \%$, baik $55 \%$ dan $36 \%$ baik sekali. Hal ini terjadi karena jalan cerita yang dibawakan sederhana dan sesuai dengan kemampuan anak, namun Alat yang digunakan masih sederhana dan masih ada beberapa anak yang belum aktif terlibat dalam bermain peran ini.

\section{- Hari Kelima}

Pada hari kelima kegiatan perbaikan pembelajarannya adalah bermain kartu ekspresi (suasana hati) dan sandiwara boneka tema binatang. Diperoleh data $0 \%$ kurang sekali, 0\% kurang, 18\% cukup, $55 \%$ baik dan $27 \%$ baik sekali. Ketika bermain kartu ekspresi dapat melatih anak untuk mau mengungkapkan suasana hatinya. Akan tetapi alat yang digunakan masih sederhana, meja kurang tinggi, belum mempunyai panggung sandiwara boneka sendiri dan masih ada beberapa anak yang belum mau duduk rapi sehingga yang lain kurang berkosentrasi dengan cerita yang disampaikan.

\section{b. Pembahasan Hasil Penelitian Perbaikan Pembelajaran}

\section{Siklus I}

\section{- $\quad$ Data kualitatif}

Secara kualitatif hasil kegiatan perbaikan pem-belajaran cukup mengalami peningkatan dibandingkan sebelumnya namun peneliti berusaha agar kemampuan anak dapat lebih berkembang lagi pada kemampuan bahasa reseptif dan ekspresinya, data yang didapat pada kegiatan Siklus I 
menjadi dasar untuk merencanakan perbaikan kegiatan pembelajaran pada siklus II

- Data kuantitatif

Tabel 9 Rekap hasil siklus I

\begin{tabular}{|c|l|c|c|c|c|c|c|}
\hline \multirow{2}{*}{ NO } & \multirow{2}{*}{ NAMA } & \multicolumn{7}{|c|}{ TANGGAL } & JUMLAH \\
\cline { 3 - 8 } & & 13 & 14 & 15 & 16 & 17 & BINTANG \\
\hline 1 & ANNISA & 2 & 3 & 3 & 2 & 4 & 14 \\
\hline 2 & ANNINDIYA & 2 & 2 & 2 & 2 & 3 & 11 \\
\hline 3 & B.RIZKY & 4 & 4 & 3 & 2 & 4 & 17 \\
\hline 4 & B.KEYSA & 4 & 4 & 4 & 3 & 4 & 19 \\
\hline 5 & DWIF & 3 & 3 & 2 & 1 & 3 & 12 \\
\hline 6 & FADHEL & 4 & 4 & 4 & 3 & 4 & 19 \\
\hline 7 & M.ARIB & 4 & 4 & 3 & 3 & 3 & 17 \\
\hline 8 & M.DINTA & 2 & 3 & 2 & 3 & 4 & 14 \\
\hline 9 & REVINA & 3 & 4 & 3 & 2 & 4 & 16 \\
\hline 10 & SALSABILA & 3 & 4 & 2 & 2 & 4 & 15 \\
\hline 11 & SYAHID & 3 & 3 & 2 & 2 & 3 & 13 \\
\hline
\end{tabular}

Dari hasil penelitian pada Siklus I yang menggunakan bermacam media dan metode pembelajaran bertujuan untuk meningkatkan kemampuan bahasa reseptif dan ekspresi, peneliti mendapatkan data kemampuan anak yang kurang sekali 1,8\%, kurang 27,2\%, cukup $36 \%, 34.6 \%$ baik dan $0 \%$ baik sekali. Hal ini menunjukan peningkatan kemampuan anak dibandingkan sebelum dilakukan penelitian perbaikan kegiatan pembelajaran, akan tetapi perlu dilakukan Siklus II untuk memperbaiki kekurangan yang ada pada siklus I sehingga hasil yang didapatkan lebih optimal dan juga untuk memenuhi standar tuntas penelitian maka untuk selanjutnya diperlukan Siklus II.

\section{Siklus II}

\section{- $\quad$ Data kualitatif}

Secara kualitatif hasil kegiatan penelitian pada Siklus II ini mengalami peningkatan secara signifikan pada kemampuan bahasa reseptif dan ekspresinya dibandingkan pada Siklus I. Hal ini berarti indikator yang diharapkan oleh peneliti dapat tercapai dengan baik.

- Data kuantitatif
Tabel 10 PENILAIAN SIKLUS II

\begin{tabular}{|c|c|c|c|c|c|c|c|}
\multirow{2}{*}{ NO } & \multirow{2}{*}{ NAMA } & \multicolumn{5}{|c|}{ Hari ke } & \multicolumn{1}{l|}{ JUMLAH } \\
\cline { 3 - 8 } & & 1 & 2 & 3 & 4 & 5 & BINTANG \\
\hline 1 & ANNISA & 4 & 5 & 4 & 4 & 4 & 21 \\
\hline 2 & ANNINDIYA & 4 & 5 & 4 & 5 & 4 & 22 \\
\hline 3 & B.RIZKY & 5 & 5 & 3 & 4 & 3 & 21 \\
\hline 4 & B.KEYYA & 5 & 5 & 5 & 5 & 5 & 25 \\
\hline 5 & DWIF & 3 & 4 & 3 & 4 & 3 & 17 \\
\hline 6 & FADHEL & 5 & 5 & 4 & 4 & 4 & 22 \\
\hline 7 & M.ARIB & 4 & 5 & 4 & 3 & 5 & 21 \\
\hline 8 & M.DINTA & 4 & 5 & 4 & 4 & 4 & 21 \\
\hline 9 & REVINA & 4 & 5 & 4 & 5 & 5 & 23 \\
\hline 10 & SALSABILA & 5 & 5 & 4 & 5 & 4 & 23 \\
\hline 11 & SYAHID & 4 & 4 & 4 & 4 & 4 & 20 \\
\hline
\end{tabular}

- $\quad$ Hasil Evaluasi

Dari hasil kegiatan Siklus II didapatkan data sebanyak $0 \%$ kurang sekali, $0 \%$ kurang, $11 \%$ cukup, $51 \%$ baik dan $38 \%$ baik sekali maka kegiatan perbaikan pembelajaran bahasa reseptif dan ekspresi anak telah memenuhi standar tuntas yang diperlukan yaitu $80 \%$ menguasai indikator yang disampaikan. Berdasarkan data di atas anak menguasai indikator dengan baik sebanyak $89 \%$. Hal ini berarti anak telah memenuhi standar tuntas yang diperlukan. Maka dari analisis data tersebut dapat dikemukakan terjadi peningkatan secara signifikan.

\section{Perbandingan Siklus I dan II}

\section{- Data kualitatif}

Secara kualitatif hasil kegiatan perbaikan pembelajaran dengan menggunakan media belajar dan metode pembelajaran yang bervariasi yang bertujuan untuk meningkatkan kemampuan bahasa reseptif dan ekspresi anak, maka berdasarkan data yang diperoleh pada Siklus I dan Siklus II, kemampuan anak yang kurang sekali pada Siklus I sebanyak $1,8 \%$ menjadi $0 \%$ pada Siklus II, yang kurang $27,2 \%$ menjadi $0 \%, 36,4 \%$ cukup menjadi $11 \%$, $34,6 \%$ baik menjadi $51 \%$ dan yang tadinya $0 \%$ baik sekali menjadi $38 \%$, jadi dari data yang diperoleh maka terjadi peningkatan secara signifikan dari Siklus I keSiklus II . 


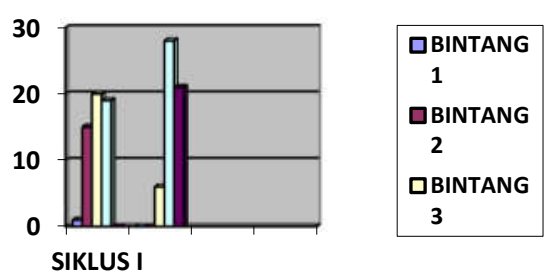

Bagan 2 Rekap hasil Perbandingan Siklus I dan Siklus II

\section{KESIMPULAN}

Dari hasil penelitian yang dilakukan pada kelompok B di TKIT NURUL IMAN pada hakikatnya telah meningkatkan kemampuan bahasa reseptif dan ekspresi pada anak, dengan bermacam media dan metode pembelajaran yang bervariasi yang disesuaikan dengan karakteristik anak. Peningkatan cukup pada Siklus I dan mengalami peningkatan yang signifikan pada Siklus II. Hal ini dapat dilihat dari data presentasi hasil belajar pada Siklus I dan Siklus II.

Setelah melaksanakan penelitian maka berdasarkan hasil temuan yang didapatkan di lapangan dan pembahasannya telah dipaparkan di atas maka upaya untuk meningkatkan kemampauan Bahasa Reseptif dan Ekspresi anak pada kelompok B di TKIT NURUL IMAN Taman Sari Bukit Damai, Padurenan, Gunungsindur, Bogor maka dapat disimpulkan sebagai berikut :

1) Sesuai dengan karakteristik anak yang unik dan berbeda maka diperlukan pembelajaran/perlakuan yang disesuaikan dengan karakternya.

2) Dengan metode bermain dan bervariasi dapat meningkatkan kemampuan Bahasa Reseptif dan Ekspresi anak.

3) Dengan motivasi dan pujian dapat meningkatkan semangat anak untuk melakukan pembelajaran.

4) Dengan media pembelajaran yang bervariasi dan memadai dapat menarik minat anak untuk antusias melakukan pembelajaran.
5) Dibutuhkan kosistensi dalam melakukan pembelajaran dan pengelolaan waktu yang tepat dari Guru.

6) Perlunya pengulangan kegiatan pembelajaran yang sama agar anak lebih mengasai indikator yang diinginkan.

7) Menggunakan konsep bahasa sederhana yang lebih sesuai dengan anak usia dini.

8) Menjelaskan sesuatu hal dengan jelas dan rinci tentang aturan permainan/materi yang disampaikan sesuai dengan tema pembelajaran.

Berdasarkan hasil penelitian Siklus I dan Siklus II yang telah diobservasi, maka peneliti memberikan saran untuk perbaikan perkembangan pada kemampuan menyerap dan mengekspresikan bahasa kepada anak TK kelompok B sebagai berikut:

\section{Lembaga sekolah}

Untuk meningkatkan kemampuan anak maka lembaga sekolah perlu memfasilitasi kegiatan belajar mengajar dengan berbagai macam media, alat, bahan ajar dan lingkungan kondusif yang memadai sehingga proses belajar mengajar dapat berjalan dengan lancar dan hasilnya dapat sesuai dengan indikator yang telah direncanakan.

\section{Tenaga pengajar/Guru}

Saat hendak melakukan pembelajaran Guru harus mempersiapkan secara matang Rencana kegiatan pembelajaran disesuaikan dengan indikator yang diharapkan, terus memotivasi anak, memberikan pujian, konsisten dengan yang diberikan dan selalu berinovasi agar pembelajarannya dapat menarik minat dan antusias anak.

\section{Bagi orang tua}

Perkembangan bahasa merupakan dasar sebelum mengembangkan aspek kemampuan yang lain maka peran orang tua yang menghabiskan waktu lebih banyak dengan anaknya perlu ikut serta dalam mengembangkan kemampauan Bahasa untuk mengembangkan semua 
aspek perkembangan sebagai bekal kehidupannya kelak.

\section{Peneliti selanjutnya}

Kepada peneliti selanjutnya diharapkan lebih dapat mengembangkan media dan metode pembelajaran yang baru dan lebih baik lagi untuk meningkatkan kemampuan reseptif dan ekspresi bahasa pada anak TK kelompok B sehingga hasilnya lebih optimal dan bermanfaat bagi dunia pendidikan anak usia dini.

\section{REFERENSI}

Aisyah, S, dkk . 2010. Perkembangan dan Konsep dasar pengembangan Anak Usia Dini. Jakarta: Universitas Terbuka.

Dhieni, N, dkk. 2009. Metode Perkembangan Bahasa. Jakarta : Universitas Terbuka.

Handayani, S dan Vienny. 2001, Merangsang empati anak. Jakarta: Umi edisi 6/XII/2001.
Handayani, S dan Zif. 2001. Bahasa asing untuk anak. Jakarta: Umi edisi 10/XIII/2001.

Handayani, S, dkk. 2001. Lima tahun pertama kehidupan masa penuh pembelajaran. Jakarta: Umi edisi 5/XIII/2001.

Handayani, S, dkk. 2001. Modal awal bagi anak gemar membaca. Jakarta: Umi edisi 5/XIII/2001.

Handayani,S , dkk. 2001. Metode permainan meningkatkan bahasa. Jakarta: Umi edisi 6/XII/2001.

Sujiono, Y dan Sujiono, B. 2001. Bermain kreatif berbasis kecerdasan jamak. Jakarta: Indeks.

Suradika, Agus, dan Dirgantara Wicaksono. 2019. Metodologi Penelitian. Tangerang Selatan: UM Jakarta Press.

Tim PKP PG-PAUD. 2012. Panduan Pemantapan Kemampuan Profesional. Jakarta: Universitas Terbuka. 